\title{
The effect of extensive interval training at altitude on the physiological, aerobic, anaerobic and various blood parameters of athletes
}

\author{
Ismail Kaya ${ }^{1 \mathrm{a}}$ \\ ${ }^{1}$ Dumlupinar University School of Physical Education and Sport, Kütahya, Turkey
}

\begin{abstract}
In this research, it was aimed to compare the physiological performances of athletes at sea level, at high altitude and 8 days after returning back to sea level on the basis of certain blood parameters, pulse and blood pressure. 12 male athletes between the ages of 19 and 23 voluntarily participated in the research. The subjects were exposed to endurance training at high altitude and at sea level between 09.00 and 11.00 in the morning. The subjects' erythrocyte (RBC), leucocyte (WBC), haemoglobin $(\mathrm{Hb})$, haematocrit $(\mathrm{HCT})$, systolic blood pressure at rest (SBPR) and diastolic blood pressure at rest (DBPR), heart rate at rest (HRR), aerobic (20m shuttle run test) and anaerobic capacity (vertical jump) levels were tested at sea level, on the 15th day at high altitude $(3120 \mathrm{~m})$ and 8 days after returning back to sea level. Statistical analysis comprised of t-test and the significance level of the results was accepted at $(\mathrm{P}<0.05)$. As a result of the research the following were determined: It can be said that high altitude trainings for fifteen days included in the annual training program of athletes can improve their performance.
\end{abstract}

Keywords: Sport, High Altitude, Physical and Physiological Properties.

\section{Introduction}

The effects of physical activities under various atmospheric conditions on performance take the attention of many researchers. In various researches, the effects of various atmospheric conditions on sportive performance have been studied and the changes both in the performance and in the body have been analyzed [10]. The first of these studies was conducted during 1968 Mexico Olympics. Later, the fact that athletes living at high altitude could show better performance in endurance sports contests at high altitude took the researchers' attention to the subject $[2,5,10]$. Generally, when they go to high altitude, people living at low altitudes show various physiological responses to deal with lack of oxygen and to prevent the fall in performance. These physiological responses appearing during training at sudden hypoxic (lack of oxygen) environment start to change as the body

${ }^{\text {a }}$ Corresponding author: ismail.kaya@dpu.edu.tr 
adapts to this environment in time; for example, tolerance to the training increases, physiological stress due to the training decreases and elevation adaptation develops [24]. As an athlete goes to higher altitude, if s/he hasn't been at that altitude before, $s /$ he is exposed to various unfamiliar ecological factors like lack of oxygen, low air pressure, rays and different aerosols [3]. As one goes to higher altitude, partial pressure of the oxygen in the air breathed falls. This falling partial oxygen pressure damages oxygenation of blood. Insufficient oxygen saturation in blood reduces oxygen delivery to all the tissues in the body. The only way for the body to compensate this is to increase the ventilation value [23]. Elevation rise causes heart rate and incites the rise in cardiac output to increase blood circulation [16]. Cardiac output instantly rises about thirty percent but this rise turns to normal with the rise in the haematocrit value of blood [17]. It is known that physical performance is affected above 5000 feet and the effect increases as the altitude rises [14]. The cause of these changes stems from hypoxia. Altitude hypoxia might affect aerobic performance negatively, which is calculated as about 1\% at every 100 meters after 1500 meters [20]. Acclimatization is adaptation to altitude and develops as short-term and longterm adaptations [18]. Trainings at high altitude lead to faster physiological changes than those at sea level, which is because of the fact that hypoxia at altitude puts the organism into stress and causes various short-term and long-term adaptations in the organism [6]. Acclimatization duration depends on elevation. For example, it is between 7 and 10 days at 9.000 feet, between 15 and 21 days at 12.000 feet and between 21 and 25 days at 15000 feet. These are only common estimations and the main factor is in fact individual differences [14]. The most important change in terms of adaptation to elevation is the increase in the capacity of oxygen delivery [9]. There is a direct relation between $\mathrm{Hb}$ content of blood and oxygen delivery to tissues. It has been established that $\mathrm{Hb}$ is inversely proportional to the fall in barometric pressure. An increase in $\mathrm{Hb}$ is a result of an increase in erythrocytes [8]. Upon raising elevation, because of a decrease in plasma volume (hemoconcentration), an increase appears in blood cells [5, 6, 12, 19, 24]. Due to dehydration through sweating and respiration while ascending high altitude, a decrease in blood plasma and an increase in HCT values occur [9]. An increase occurs in the myoglobin content of skeletal muscles together with a change in its characteristics and in the mitochondria number [7]. As one goes to high altitude, certain adaptations appear in human body in order to adapt to environmental hypoxia. For this reason, it was aimed in the research to determine the acute changes appearing in the aerobic strength, anaerobic strength, certain blood parameters, pulse and blood pressure of 12 male athletes before altitude, at altitude and after altitude.

\section{Method}

The participants of the study were voluntary athletes who had actively been engaged in various sports for average seven years. The subjects were $22 \pm 2.48$ years old, with $183.58 \pm 7.01 \mathrm{~cm}$ height and $74.26 \pm 12.63 \mathrm{~kg}$ weight. RBC, WBC, Hb, HCT, SBPR, DBPR, HRR, Aerobic Strength (20m shuttle run test) and Anaerobic Strength (Vertical Jump Test) levels of the athletes were analyzed on the $15^{\text {th }}$ day of high altitude training and on the $8^{\text {th }}$ day of sea level training.

\subsection{Training Program Conducted on the Subjects}

The athletes were exposed to endurance training between 09.00 and 11.00 in the morning at high altitude and at sea level. During the training at high altitude, the atmospheric heat was between $+12^{\circ} \mathrm{C}$ and $+25^{\circ} \mathrm{C}$ while at sea level it was between $+20^{\circ} \mathrm{C}$ and $+32^{\circ} \mathrm{C}$. Strict attention was paid to applying the same diet, schedule and sleeping 
routine at both high altitude and sea level.

\section{Training}

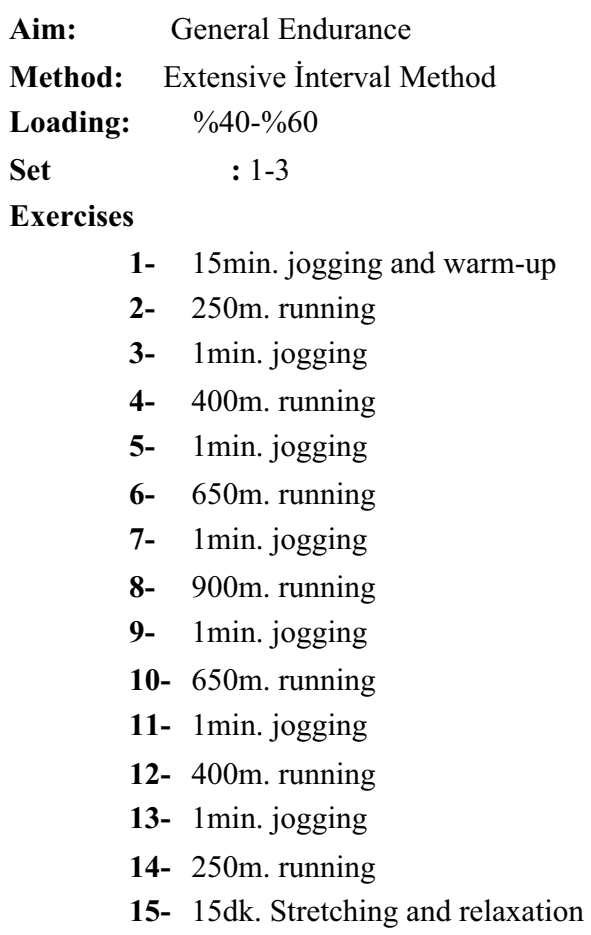

\subsection{Measurement Methods}

\subsubsection{Hematologic Measurements}

The first measurements of blood $\mathrm{RBC}, \mathrm{WBC}, \mathrm{Hb}, \mathrm{HCT}$ values were done at sea level at hospital laboratory by experts using a full automatic "Coulter Stks" hemogram as the subjects were seated at rest. The second measurements were conducted at high altitude at hospital laboratory by experts using a full automatic "Coulter Stks" hemogram as the subjects were seated at rest. The third measurements were conducted again at sea level at hospital laboratory by experts using a full automatic "Coulter Stks" hemogram as the subjects were seated at rest.

\subsubsection{Measurement of Aerobic Capacity: 20m Shuttle run Test}

The researcher had previously determined and marked the $20 \mathrm{~m}$ distance to be covered during the tests at sea level and at high altitude. The subjects were asked to run $20 \mathrm{~m}$ distance and back in the gymnasium having previously determined and marked. The running speed was checked at certain intervals with a tape that gave a signal sound. The subject was asked to start his run upon hearing the first signal and to have reached the other line by the time he heard the second signal. Upon hearing the second signal, he was asked to return back to the start line and the process continued as such with signals. The speed was slow at the beginning and increased every ten seconds. Whenever the subject passed every $20 \mathrm{~m}$ line, it was recorded on a form [26]. 


\subsubsection{Measurement of Heart Rate at Rest}

Heart rates of the subjects at rest were measured with stethoscope (Auscultation) for 15sec. as seated when they rested and were recorded after multiplying them by four [15].

\subsubsection{Measurement of Blood Pressure}

The subjects' blood pressures are taken as seated. Stethoscope is placed right above the elbow joint over brachial artery (The middle point of the arm when the palm looks up). Sphygmomanometer is inflated rapidly until the pressure reaches $160 \mathrm{mmHg}$ and then is deflated slowly until the first strong sound is heard. This is called the "Krotkoff" sound and it is heard when blood starts to pass the artery because the pressure on the artery has been reduced. This first "Krotkoff" sound is accepted as systolic blood pressure. The pressure reduction continues and the indicator is read when the beat sound suddenly decreases or disappears. This is accepted as diastolic blood pressure [18].

\subsubsection{Measurement of Anaerobic Capacity: Vertical Jump Test}

The athletes were asked to stand up on the rubber plate put on the floor and then the digital measurement tool showing the jump measurement was placed on their belly level and the belt was fastened while their arms were up. After the rope between the digital measurement tool and the rubber plate under his feet was stretched right in the middle of the feet and the measurement tool was reset, each athlete was asked to jump vertically by bending his knees and getting strength from his arms and to fall back on the rubber plate on the floor twice. The best score of the two jumps was recorded. Also, the body weights of the subjects were measured with precision scales and anaerobic strength calculation was done with the formula below $[15,4]$.

$$
\begin{aligned}
& P=(\sqrt{4} .9(\text { Weight }) \sqrt{ } \mathrm{D}) \\
& \mathrm{P}=\text { Power } \\
& \mathrm{D}=\text { Vertical Jump Distance. }
\end{aligned}
$$

\section{Findings}

According to the measurement results of the subjects at high altitude, a $2.16 \%$ increase was seen in their RBC measurements, a \%2.90 increase was seen in their HCT measurements and a $4.58 \%$ increase was seen in their vertical jump measurements while a $6.47 \%$ decrease was seen in their $20 \mathrm{~m}$ shuttle run test measurements. The differences in the subjects' RBC, HCT, 20m shuttle run test and vertical jump measurement values weren't statistically significant $(\mathrm{P}>0.05)$.

According to the measurement results of the subjects at high altitude, a \%26.21 increase in WBC measurements, $5.35 \%$ in $\mathrm{Hb}$ measurements, a $10.02 \%$ increase in HRR measurements, a $24.56 \%$ increase in SBPR measurements and an $11.46 \%$ increase in DBPR measurements were found. The differences in the subjects' WBC, Hb, HRR, SBPR and DBPR measurement values were statistically significant $(\mathrm{P}<0.05)$.

According to the measurement results of the subjects at high altitude, a $7.40 \%$ decrease in $\mathrm{RBC}$ measurements, a $6.60 \%$ decrease in $\mathrm{Hb}$ measurements and a $3.27 \%$ decrease in HCT measurements were found while a $0.28 \%$ increase was seen in vertical jump measurements. The differences in the subjects' RBC, Hb, HCT and vertical jump measurement values weren't statistically significant $(\mathrm{P}>0.05)$. 
Table 1. Analysis results

\begin{tabular}{|c|c|c|c|c|c|c|}
\hline Variables & & $\mathbf{N}$ & Mean & Std Deviation & X1-x2 \% & $\mathbf{t}$ \\
\hline Sea level-1 & $\mathrm{RBC}$ & 12 & 5,36750 & ,365762 & 2,16 & 0,424 \\
\hline Altitude ( $15^{\text {th }}$ day) & & & 5,48667 &, 350955 & & \\
\hline Sea level-1 & WBC & 12 & 7,008333 & 1,4145082 & 26,21 & 0,001 \\
\hline Altitude & & & 9,49667 & 1,5692838 & & \\
\hline Sea level-1 & $\mathrm{Hb}$ & 12 & 15,917 & ,9173 & 5,35 & 0,003 \\
\hline Altitude & & & 16,817 & 1,0152 & & \\
\hline Sea level-1 & HCT & 12 & 48,108 & 2,9222 & 2,90 & 0,235 \\
\hline Altitude & & & 49,542 & 2,8234 & & \\
\hline Sea level-1 & HRR & 12 & 64,33 & 4,658 & 10,02 & 0,002 \\
\hline Altitude & & & 71,50 & 5,266 & & \\
\hline Sea level-1 & SBPR & 12 & 110,00 & 6,030 & 24,56 & 0,000 \\
\hline Altitude & & & 145,83 & 10,836 & & \\
\hline Sea level-1 & DBPR & 12 & 70,8333 & 6,33652 & 11,46 & 0,007 \\
\hline Altitude & & & 80,0000 & 8,52803 & & \\
\hline Sea level-1 & Aerobic & 12 & 46,350 & 3,9860 & 6,47 & 0,088 \\
\hline Altitude & Capacity & & 43,350 & 4,2507 & & \\
\hline Sea level-1 & Anaerobic & 12 & 110,92 & 18,928 & 4,58 & 0,531 \\
\hline Altitude & Capacity & & 116,25 & 21,959 & & \\
\hline
\end{tabular}

Table 2. Analysis results

\begin{tabular}{|c|c|c|c|c|c|c|}
\hline Variables & & $\mathbf{N}$ & Mean & Std Deviation & X1-x2\% & $\mathbf{t}$ \\
\hline Altitude & $\mathrm{RBC}$ & 12 & 5,48667 & ,350955 & 7,40 & 0,121 \\
\hline Sea level-2 ( $8^{\text {th }}$ day) & & & 5,08833 &, 780837 & & \\
\hline Altitude & WBC & 12 & 9,491667 & 1,5692838 & 26,35 & 0,002 \\
\hline Sea level-2 & & & 6,995833 & 1,9337268 & & \\
\hline Altitude & $\mathrm{Hb}$ & 12 & 16,817 & 1,0152 & 6,60 & 0,14 \\
\hline Sea level-2 & & & 15,708 & 1,0238 & & \\
\hline Altitude & HCT & 12 & 49,542 & 2,8234 & 3,27 & 0,220 \\
\hline Sea level-2 & & & 47,925 & 3,4168 & & \\
\hline Altitude & HRR & 12 & 71,50 & 5,266 & 11,88 & 0,000 \\
\hline Sea level-2 & & & 63,00 & 4,553 & & \\
\hline Altitude & SBPR & 12 & 145,83 & 10,836 & 26,85 & 0,000 \\
\hline Sea level-2 & & & 106,67 & 6,513 & & \\
\hline Altitude & DBPR & 12 & 80,0000 & 8,52803 & 14,58 & 0,001 \\
\hline Sea level-2 & & & 68,3333 & 5,77350 & & \\
\hline Altitude & Aerobic & 12 & 43,350 & 4,2507 & 14,68 & 0,000 \\
\hline Sea level-2 & Capacity & & 50,817 & 4,2893 & & \\
\hline Altitude & Anaerobic & 12 & 116,25 & 21,959 & 0,28 & 0,917 \\
\hline Sea level-2 & Capacity & & 116,58 & 22,516 & & \\
\hline
\end{tabular}

According to the measurement results of the subjects at high altitude, a $26.35 \%$ decrease in WBC measurements, a $11.88 \%$ decrease in HRR measurements, a $26.85 \%$ decrease in SBPR measurements and a $14.58 \%$ decrease in DBPR measurements were found while a $14.68 \%$ increase was determined in $20 \mathrm{~m}$ shuttle run test test measurements. The differences in the subjects' WBC, HRR, SBPR, DBPR and 20m shuttle run test measurement values were statistically significant $(\mathrm{P}<0.05)$.

The differences between the RBC, WBC, Hb, HCT, HRR, SBPR, DBPR and anaerobic measurement values of the subjects before going to high altitude and 8 days after turning back to sea level weren't found to be statistically significant $(\mathrm{P}>0.05)$. Only the differences between the aerobic measurement values of the subjects were found to be statistically significant $(\mathrm{P}<0.05)$. In the measurements shown in Table-3, it was determined that a $8.77 \%$ significant increase occurred in the aerobic capacity 8 days after returning back from 
high altitude and a $4.85 \%$ increase happened in the anaerobic capacity, but this increase was statistically insignificant.

Table 3. Analysis results

\begin{tabular}{|c|c|c|c|c|c|c|}
\hline Variables & & $\mathbf{N}$ & Mean & Std Deviation & $\mathrm{X} 1-\mathrm{x} 2 \%$ & $\mathbf{t}$ \\
\hline Sea level-1 & $\mathrm{RBC}$ & 12 & 5,36750 & ,365765 & 5,34 & 0,274 \\
\hline Sea level-2 & & & 5,08833 & ,780837 & & \\
\hline Sea level-1 & WBC & 12 & 7,008333 & 1,4145082 & 0,14 & 0,986 \\
\hline Sea level-2 & & & 6,995833 & 1,9337268 & & \\
\hline Sea level-1 & $\mathrm{Hb}$ & 12 & 15,917 & ,9173 & 1,31 & 0,605 \\
\hline Sea level-2 & & & 15,708 & 1,0238 & & \\
\hline Sea level-1 & HCT & 12 & 48,108 & 2,9222 & 0,37 & 0,889 \\
\hline Sea level-2 & & & 47,925 & 3,4168 & & \\
\hline Sea level-1 & HRR & 12 & 64,33 & 4,658 & 2,06 & 0,486 \\
\hline Sea level-2 & & & 63,00 & 4,553 & & \\
\hline Sea level-1 & SBPR & 12 & 110,00 & 6,030 & 3,02 & 0,207 \\
\hline Sea level-2 & & & 106,67 & 6,513 & & \\
\hline Sea level-1 & DBPR & 12 & 70,8333 & 6,33652 & 3,58 & 0,323 \\
\hline Sea level-2 & & & 68,3333 & 5,77350 & & \\
\hline Sea level-1 & Aerobic & 12 & 46,350 & 3,9860 & 8,77 & 0,015 \\
\hline Sea level-2 & Capacity & & 50,817 & 4,2893 & & \\
\hline Sea level-1 & Anaerobic & 12 & 110,92 & 18,928 & 4,85 & 0,521 \\
\hline Sea level-2 & Capacity & & 116,58 & 22,516 & & \\
\hline
\end{tabular}

\section{Discussion and Conclusion}

As a result of the study, during the first measurements at sea level, the RBC values were found $5.36 \pm 0.36 \mathrm{million} / \mathrm{mm}^{3}$ and, during the second measurements at high altitude, they were found $5.48 \pm 0.35 \mathrm{million} / \mathrm{mm}^{3}$. The increase in the $\mathrm{RBC}$ values was determined to be statistically insignificant $(\mathrm{P}>0.05)$. During the third measurements 8 days after returning back to sea level, the RBC values were found $5.08 \pm 0.78$ million $/ \mathrm{mm}^{3}$. Accordingly, comparing the RBC values at the first measurements before going to high altitude and at the third measurements 8 days after returning back to sea level, a 5.34\% fall was seen; however, this fall was determined to be statistically insignificant $(\mathrm{P}>0.05)$. Despite insignificant findings of the study, the RBC values at high altitude were still higher than those at sea level. It is thought that the duration at high altitude might have caused an increase in RBC numbers in blood. Since the oxygen rate will increase due to the rise in the RBC numbers, this might have affected the performance of the athletes positively. The test results confirm that the RBC number decreased at sea level. Sayan et al. [28] determined in their study on 14 athletes that the mean RBC values obtained during their measurements before going to high altitude $(850 \mathrm{~m})$ was $5.03 \pm 0.55 \times 1000 \mathrm{~mm}^{3}$ and it was $4.68 \pm 0.48 \times 1000$ $\mathrm{mm}^{3}$ during the second measurement on the fifth day at high altitude $(1800 \mathrm{~m})$. Robert et al. (30) determined that during the first measurements before going to high altitude the total red cell volume was $\mathrm{ml} / \mathrm{kg} .29 .2 \pm 4.0$, while it was $\mathrm{ml} / \mathrm{kg} .31 .5 \pm 4.1$ during the second measurements on the twenty-eighth day at high altitude.

During the first measurements at sea level, the subjects' mean WBC values was found $7.00 \pm 1.41 \mathrm{bin} / \mathrm{mm}^{3}$ while it was $9.49 \pm 1.56 \mathrm{bin} / \mathrm{mm}^{3}$ during the second measurements at high altitude. The increase between these two measurements was found to be statistically significant $(\mathrm{P}<0.05)$. During the third measurements 8 days after returning back to sea level, the WBC values were found $6.99 \pm 1.93 \mathrm{bin} / \mathrm{mm}^{3}$. As seen in Graph 2, the decrease in the WBC values between the second measurements at high altitude and the third 8 days after returning back to sea level is statistically significant $(\mathrm{P}<0.05)$. Sayan et al. [28] 
determined in their study on 14 athletes that the mean WBC values obtained during their measurements before going to high altitude $(850 \mathrm{~m})$ was $6.88 \pm 1.39 \times 1000 \mathrm{~mm}^{3}$ and it was $7.17 \pm 1.01 \times 1000 \mathrm{~mm}^{3}$ during the second measurement on the fifth day at high altitude $(1800$ $\mathrm{m})$. Robert et al. [30] determined that during the first measurements before going to high altitude the total blood volume was $\mathrm{ml} / \mathrm{kg}$. $83.7 \pm 8.5$, while it was $\mathrm{ml} / \mathrm{kg} .31 .5 \pm 4.1$ during the second measurements on the twenty-eighth day at high altitude. Fox et al. [14] stated that training at high altitude causes higher rate of physiological changes compared with the one at sea level and added that this is because the fact that altitude hypoxia leads to a force causing physiological changes similar to those caused by physical training. It is thought that different factors of altitude are effective in the decrease in the RBC and WBC values at sea level.

During the first measurements of the subjects' mean $\mathrm{Hb}$ values at sea level was found $15.91 \pm 0.91 \mathrm{~g} / 100 \mathrm{ml}$, while it was $16.81 \pm 1.01 \mathrm{~g} / 100 \mathrm{ml}$ at high altitude. The differences between the values at high altitude and sea level were found statistically significant $(\mathrm{P}<0.05)$. A 5.35\% increase was seen as one went to high altitude compared with sea level. When climbed down to sea level, during the measurements on the 8th day at sea level, $\mathrm{Hb}$ values were found $15.70 \pm 1.02 \mathrm{~g} / 100 \mathrm{ml}$ and a $6.60 \%$ decrease was determined. Özcan [21], found in his study in 1990 conducted on 16 athletes at a ski centre on Mount Erciyes in the city of Kayseri at $2150 \mathrm{~m}$ that, prior to the fortnight camping, their mean haemoglobin amount $14.9 \pm 0.3 \mathrm{~g} / 100 \mathrm{ml}$ whereas it became $15.5 \pm 0.2 \mathrm{~g} / 100 \mathrm{ml}$ after the camping. In Doğar's [9] research, mean haemoglobin values was $16.30 \pm 0.61 \mathrm{~g} / 100 \mathrm{ml}$ in Erzurum, while it was $14.48 \pm 0.48 \mathrm{~g} / 100 \mathrm{ml}$ in İzmir-3 measurement and the difference between the measurements was statistically significant $(\mathrm{P}<0.01)$. It is seen that Özcan and Doğar's studies confirm this study's Hb values. Dante and Javier [29], determined in their study conducted on 11 subjects living at high altitude $(4540 \mathrm{~m})$ that the subjects' $\mathrm{Hb}$ value was $18.5 \pm 1.8 \mathrm{~g} / \mathrm{dL}$ in their first measurements at $4540 \mathrm{~m}$, whereas it was $13.5 \pm 0.81 \mathrm{~g} / \mathrm{dL}$ in their second measurement done two years after the subjects came to sea level.

The subjects mean HCT values was found $\% 48.10 \pm 2.92$ at sea level, whereas it was $\% 49.54 \pm 2.82$ at high altitude. The change between these two values wasn't found statistically significant $(\mathrm{P}>0.05)$. It was determined during measurements that as the athletes went to high altitude, their HCT rate increased $2.90 \%$. During the measurements on the $8^{\text {th }}$ day at sea level, HCT measurement values were $\% 47.92 \pm 3.41$ and a $3.27 \%$ decrease was found in the HCT values. Ergen and Açıkada [1] state that an increase in haematocrit values might occur during long-term adaptation to high altitude. Özcan [21], found in his study that the mean haematocrit amount prior to a fortnight camping at high altitude was $\% 45.7 \pm 0.3$ whereas after the fortnight camping period the mean became $\% 47 . \pm 40.7$. The increase was found statistically significant $(\mathrm{P}<0.05)$. Dante and Javier [29], determined in their study conducted on 11 subjects living at high altitude $(4540 \mathrm{~m})$ that the subjects' Hct value was $55.4 \pm 5.03$ in their first measurements at $4540 \mathrm{~m}$, whereas it was $41.9 \pm 2.8$ in their second measurement done two years after the subjects came to sea level.

During the measurements at sea level, the subjects' mean HRR values was found 64.33 $\pm 4.65 \mathrm{at} / \mathrm{min}$, whereas it was found $71.50 \pm 5.26 \mathrm{at} / \mathrm{min}$. during the measurements at high altitude. The change between these two values was found statistically significant $(\mathrm{P}<0.05)$. When the athletes climbed high altitude, a $10.02 \%$ increase was found in their heart rate per minute. The measurements on the $8^{\text {th }}$ day after returning back to sea level showed that their HRR values were $63.00 \pm 4.55 \mathrm{at} / \mathrm{min}$. and the difference between the two values was found statistically significant. A $11.88 \%$ fall was determined at sea level. The HRR means in this study are supported by the values put forward in the literature. In Zorba's [25] study, while the subjects' HRR mean was $70.4 \pm 8$. 9at $/ \mathrm{min}$. before altitude, it rose to $76.06 \pm 8.6 \mathrm{at} / \mathrm{min}$. at high altitude and fell down to $68.8 \pm 7.8 \mathrm{at} / \mathrm{min}$. after altitude. One of the most important reasons for this is the decrease in the oxygen pressure as altitude rises. Savaş et al. [22], as a 
result of their interval training at $1890 \mathrm{~m}$, found that while the HRR was $74.5 \pm 5.59 \mathrm{at} / \mathrm{min}$. before altitude, it fell down to $73.0 \pm 3.72 \mathrm{at} / \mathrm{min}$. after the 8 -week training. Frisoncho et al. [15] determined that heart rate values are less at lower altitudes compared with higher altitudes in Peru and America. Some other researchers found that heart rate rises $50 \%$ at high altitude. Ergen [13] states that tissues try to get enough blood through the increase in respiration frequency and circulation system heart rate at altitude.

The subjects' mean SBPR values were found $110.00 \pm 6.03 \mathrm{mmHg}$ at sea level measurements, while they were found $145.83 \pm 10.83 \mathrm{mmHg}$ at high altitude measurements. The difference between the two values was found statistically significant $(\mathrm{P}<0.05)$. When the athletes climbed high altitude, a $\% 24.56 \mathrm{mmHg}$ increase was found in their SBPR values. During the measurements on the $8^{\text {th }}$ day after returning back to sea level, the SBPR values were determined to be $106.67 \pm 6.51 \mathrm{mmHg}$. The difference between the two values was determined to be statistically significant $(\mathrm{P}<0.05)$. When the athletes descended to sea level, a $\% 26.85 \mathrm{mmHg}$ fall was seen in their SBPR values. The literature supports this study. Zorba [25], found in his research on 15 male athletes of METU Physical Training and Sports Department that their systolic blood pressure was $111.5 \pm 6.6 \mathrm{mmHg}$ before altitude, $117.0 \pm 5.02 \mathrm{mmHg}$ at altitude and $116.26 \pm 7.51 \mathrm{mmHg}$ after altitude. Doğar [9] found in his study that the mean SBPR values was $111.87 \pm 4.16 \mathrm{mmHg}$ in Erzurum, 110.00 $\pm 6.32 \mathrm{mmHg}$ in İzmir-1 measurements, $107.12 \pm 5.72 \mathrm{mmHg}$ in İzmir-2 measurements and $114.00 \pm 5.93 \mathrm{mmHg}$ in İzmir-3 measurements. The change was found statistically significant.

The subjects' mean DBPR values were found $70.83 \pm 6.33 \mathrm{mmHg}$ at sea level measurements, while they were found $80.00 \pm 8.52 \mathrm{mmHg}$ at high altitude measurements. The difference between the two values was found statistically significant $(\mathrm{P}<0.05)$. When the athletes climbed high altitude, a $\% 11.46 \mathrm{mmHg}$ increase was found in their DBPR values. During the measurements on the $8^{\text {th }}$ day after returning back to sea level, the DBPR values were determined to be $68.33 \pm 5.77 \mathrm{mmHg}$. The difference between the two values was determined to be statistically significant $(\mathrm{P}<0.05)$. When the athletes descended to sea level, a $\% 14.58 \mathrm{mmHg}$ fall was seen in their DBPR values. The literature supports this study. Zorba (25), found in his research on 15 male athletes of METU Physical Training and Sports Department that their diastolic blood pressure was $67.73 \pm 10.8 \mathrm{mmHg}$ before altitude, $67.5 \pm 10.2 \mathrm{mmHg}$ at altitude and $70.13 \pm 8.79 \mathrm{mmHg}$ after altitude. Doğru [11] concludes as a result of his studies that high altitude has a positive effect on respiration and cardiovascular system.

The subjects' mean aerobic capacity values were found $46.35 \pm 3.98 \mathrm{ml} / \mathrm{kg} / \mathrm{min}$ at sea level measurements, while they were found $43.35 \pm 4.25 \mathrm{ml} / \mathrm{kg} / \mathrm{min}$ at high altitude measurements. The difference between the two values wasn't found statistically significant. When the athletes climbed high altitude, a $6.47 \%$ decrease was found in their aerobic capacity values. During the measurements on the $8^{\text {th }}$ day after returning back to sea level, the aerobic capacity values were determined to be $50.81 \pm 4.28 \mathrm{ml} / \mathrm{kg} / \mathrm{min}$. The difference between the two values was determined to be statistically significant. When the athletes descended to sea level, a $14.68 \%$ increase was seen in their aerobic capacity values. The literature supports this study.

Fox et al. [14] state as a result of their study that capability to do physical work over $1527 \mathrm{~m}$ (5000feet) decreases depending on hypoxia and high altitude especially affects aerobic activities. Zorba [25] found in his research on 15 male athletes of METU Physical Training and Sports Department that found in his research on the aerobic capacities of athletes of METU Physical Training and Sports Department that the subjects' aerobic capacity values before and after altitude showed significant differences. Doğar [9] found in his study on 8 athletes that the subjects' mean maximal $\mathrm{VO} 2$ values were $58.85 \pm 2.75 \mathrm{ml} / \mathrm{kg} / \mathrm{min}$ in Erzurum and $62.81 \pm 3.19 \mathrm{ml} / \mathrm{kg} / \mathrm{min}$ in the measurements one the 
$8^{\text {th }}$ day of the camp in İzmir. The increase was found to be statistically insignificant.

The subjects' mean anaerobic capacity values were found $110.92 \pm 18.92 \mathrm{~kg}-\mathrm{m} / \mathrm{sec}$ at sea level measurements, while they were found $116.25 \pm 21.95 \mathrm{~kg}-\mathrm{m} / \mathrm{sec}$ at high altitude measurements. The difference between the two values wasn't found statistically significant. When the athletes climbed high altitude, a $4.58 \%$ increase was found in their anaerobic capacity values. During the measurements on the $8^{\text {th }}$ day after returning back to sea level, the anaerobic capacity values were determined to be $116.58 \pm 22.51 \mathrm{~kg}-\mathrm{m} / \mathrm{sec}$. The difference between the two values was determined to be statistically insignificant. When the athletes descended to sea level, a $4.85 \%$ increase was seen in their anaerobic capacity values. Fox et al. [14] found in their study on 26 students with average age of 15 that the mean anaerobic strength was $69.6 \mathrm{~kg}-\mathrm{m} / \mathrm{sec}$. In the same research, the fact that the mean anaerobic strength of male athletes between 20 and 30 years of age was $140-175 \mathrm{~kg}-\mathrm{m} / \mathrm{sec}$ was considered mediocre, whereas $176-210 \mathrm{~kg}-\mathrm{m} / \mathrm{sec}$ was considered good. Baydil [27] determined in his study on 32 subjects in 2005 that the mean anaerobic strength of the subjects during the first measurement before ascending to high altitude $(730 \mathrm{~m})$ was 136.58 $\pm 4.76 \mathrm{~kg}-\mathrm{m} / \mathrm{sec}$, while it was $140.25 \pm 3.75 \mathrm{~kg}-\mathrm{m} / \mathrm{sec}$ during the measurement at high altitude $(1850 \mathrm{~m})$. The information gathered through literature review supports this study in that it shows that training at high altitude doesn't have a positive effect on anaerobic capacity.

As a result of the research the following were determined: athletes making an effort at high altitude should be supported with vitamins and minerals, should do regular sleeping and resting, and exercises that will cause lactic acid accumulation shouldn't be done on the first days. Training at high altitude especially affects aerobic activities. As altitude rises, the physiological and hematologic differences arising from the decrease in oxygen level directly affects the athletes' performance. Accordingly, it can be said that high altitude trainings for fifteen days included in the annual training program of athletes can improve their performance.

\section{References}

1. C. Açıkada, E. Ergen, Yükseklik Antrenmanı, Bilim ve Teknik Dergisi 7: 16 (1986).

2. N. AKGÜN, Egzersiz Fizyolojisi, 4. Bask1,I. Cilt, Ege Üniversitesi Basımevi, İzmir (1993).

3. C. ARSLAN, Spor ve Çevre Etkileşimi, Spor ve Tıp, Yı1: 10, 1-2, 5-13, Ocak-Nisan (2002).

4. E. Başer, Spor Hekimliği, Milli Eğitim Gençlik ve Spor Bakanlı̆̆ı BTGM Yayınları,196 (1986).

5. E. Ergen et all., Spor Fizyolojisi, Anadolu Üniversitesi yayını, Yayın No: 584, Eskişehir (1993).

6. Fox, Bowers, Foss (çeviri Mesut Cerit). Beden Eğitimi ve Sporun Fizyolojik Temelleri, Bağırgan Yayınevi, Ankara, sy. 381-386 (1999).

7. RJ. Davis, CR. Bull, JV. Rosceo, DA. Roscoe, Physical Education and The Study of Sport, Second Edition, Mwby Barcelona, Spain, $72-73$ (1994).

8. FW. Dick, Sports Training Principles. Third Edition A\&C Black Publishers Ltd, London, 32 (1997).

9. V. Doğar, Yüksek İrtifada Yaşayan Elit-Orta-Uzun Mesafe Koşucuların Yüksek İrtifa ve Deniz Seviyesindeki Fiziksel Performansları ile Çeşitli Kan Parametrelerinin Karşılaştırılması, Beden Eğitimi ve Spor Bilimleri Dergisi 1:17 (1996).

10. E. ZORBA, G. DOGRU, Y. TAŞKIRAN, OTDÜ Beden Eğitimi ve Spor Bölümü Öğrencilerinin Yükseltiden Sonra Bazı Fizyolojik Parametrelerindeki Değişikliklerin İncelenmesi, Spor Hekimliği Dergisi, 30, 1-12, (1995). 
11. A. Doğru, Dăgcılık Yüksek Irtifa, Başbakanlık Gençlik ve Spor Genel Müdürlüğü Yayınlar1, 149 (1989).

12. M. Günay, I. Cicioğlu, K. Tamer, Spor Fizyolojisi ve Performans Ölçümü, Gazi Kitapevi, 283-289 (2006).

13. E. Ergen, Değişik Ortam Koşullarında Egzersiz, Maya Matbaacılık, 41 (1992).

14. Fox, Bowers, Foos. The Physiogical Basis of Physical Education and Athctional. W.B. Saunders Company Fourt Edition, America, 18-19 (1988).

15. AR. Frisoncho, Functional Adaptation to High Altitude Hypoxia. Sarence, 187-313 (1975).

16. D. Graetzer, High Altitude and Its Effects on Exercise Performance, http//www.liveninks.com/sumerial/oxy

17. Guyton\&Hall. Tıbbi Fizyoloji, Nobel T1p Kitapevi, İstanbul, 48 (1996).

18. Günay, M. Egzersiz Fizyolojisi, Bağırgan Kitapevi Ankara, 27 (1998).

19. Kalyon, T.A. Spor hekimliği, Gata basımevi, Ankara (1994).

20. BID. Levine, J.A. Siraybundersen, Provtial Approach to Altitude Training, J. Sports Med.13: 66 (1992).

21. O. Özcan, Yükseltide Yapılan Antrenmanın Bazı Kan Parametreleri Üzerine Etkileri. Erciyes University Sağlık Bilimleri Enstitüsü, Yüksek Lisans Tezi, Kayseri (1992). TEZ

22. S. Savaş, Comparison of the Effect of İnterval Training at Sea Level and High Altitude on some Physical Properties, XI Balkan Congress of Sports Medicine, VII Turkish Sports Medicine Congress, Antalya , 35 (1999).

23. H. Anderson, H. Eriksan, N. Rerss, The Short Term Physiologic Effects of High Altitude, http//www.physiologh/pagefinl.htm.

24. G. Tiryaki, Yüksek Rakımda Egzersiz ile İlgili Son Yaklaşımlar, I.Yüksek İrtifa ve Spor Bilimleri Kongresi (1991).

25. E. Zorba, G. Doğu, MA. Ziyagil, Yükseltiden Önce ve Sonra Bazı Fizyolojik Parametrelerdeki Değişiklikler. Spor ve Tip 2 8-12, (1995).

26. K. Tamer, Sporda Fiziksel-Fizyolojik Performansın Ölçülmesi ve Değerlendirilmesi, Bağırgan Yayınevi, 131 (2000)

27. B. Baydil, Sedenter Erkeklerde Yüksek İrtifada Uygulanan Yoğun İnterval Antrenman Programının Aerobik ve Anaerobik Kapasiteye Etkisi, Kastamonu Eğitim Dergisi, 13 (2005).

28. H. Sayan, E. Çetin, I. Yarım, B. Gönül, Yüksek İrtifada Antrenman Yapan Kayakçılarda C Vitaminin Eritrosit Süperoksit Dismutaz Enzim Aktivitesi ve Lipid Peroksidasyonu Düzeylerine Etkisi,T Klin J Med Sci, 20 (2000)

29. P. Dante, Penaloza, Javier Aries- Stella, The Heart and Pulmonary Circulation at High Altitudes:Healthy Highlanders and Chronic Mountain Sickness, Journal of the American Hearth Association , 115, 1132-1146 (2007).

30. F. Robert, Chapman, James.Stray-Gundersen, D. Benjamin, Leveine,İndividual Variation in Response to Altitude Training, The American Physiological Society, 1448-1456 (1998). 